\title{
Kejituan Datum Carta dalam Tempoh Cerapan Pasang Surut: Kajian Kes di Teluk Ewa, Pulau Langkawi
}

\author{
(An Accuracy of Chart Datum in the Tidal Observation Period: Case Study for \\ Teluk Ewa, Pulau Langkawi)
}

Khairul Nizam Abdul Maulud*, Zaaim Hasan \& Othman A. Karim

\section{ABSTRAK}

\begin{abstract}
Kajian ini menghuraikan kejituan datum carta di stesen pasang surut Teluk Ewa, Pulau Langkawi. Data cerapan pasang surut selama 19 tahun di Teluk Ewa diproses dan dianalisa dengan menggunakan perisian pasang surut iaitu "RMN Asean Australia Tidal Software” bagi menentukan nilai datum carta model cerapan 19 tahun (Datum rujuk), setiap tahun, 6 bulan, 3 bulan dan bulanan. Kejituan datum diuji mengikut pematuhan piawai Pertubuhan Hidrografi Antarabangsa (IHO). IHO menetapkan ralat datum $5 \mathrm{~cm}$ bagi pengukuran kelas khas dan $10 \mathrm{~cm}$ bagi pengukuran kelas 1 dan ke bawah. Keputusan menunjukkan sisihan piawai bagi semua model datum carta (satu sigma) adalah kurang daripada 10cm namun tidak pada dua sigma. Aliran sisihan piawai datum carta menunjukkan ia semakin baik sekiranya tempoh cerapan semakin panjang. Namun begitu, tempoh cerapan tahunan merekodkan sisihan datum carta kurang daripada 11 cm sepanjang 19 tahun. Kejadian pasang surut bersifat lokasi khusus maka pendekatan menyeluruh mengenai kejituan datum carta negara hanya dapat dimodelkan setelah kajian dilaksanakan terhadap semua stesen pasang surut.
\end{abstract}

Kata kunci: Perubahan cuaca; IHO; kenaikan paras laut; analisis statistik; hidrografi

\section{ABSTRACT}

This study elaborates the precision of chart datum at Teluk Ewa, Langkawi Island. Observed tidal data for 19 years at Teluk Ewa tidal station were processed and analyzed using the "RMN Asean Australia Tidal Software" to determine values of chart datum for 19 years observation models (Reference datum), yearly, 6 monthly, 3 monthly and monthly. Datum precisions were tested conforming with International Hydrographic Organization (IHO) Standard. IHO had determined that datum error for special class survey must be less than $5 \mathrm{~cm}$ and $10 \mathrm{~cm}$ for first class survey and below. Results showed that the standard deviations (one sigma) for all model of chart datum are less than $10 \mathrm{~cm}$, however at two sigma it proved otherwise. The trend of chart datum standard deviation indicated that longer period of observation record better standard deviations. Tides are site specific, therefore holistic approach of the country's chart datum precision could only be modeled once the studies on all tidal stations are completed.

Keywords: Bandwidth; phase range; phase slope; triangular loop; transparent conductive film

\section{PENGENALAN}

Datum Carta merupakan aras rujukan pasang surut bagi kedalaman carta nautika, pengukuran hidrografi dan juga ramalan pasang surut (Estopinal 2009; Kavanagh, 2009; Mills \& Dodd, 2014). Ini bermakna kedalaman batimetri yang tertera dalam carta nautika dan ketinggian pasang surut pada jadual pasang surut dirujuk kepada aras yang sama. Menurut Charlier dan Finkl (2009), seluruh negara di dunia merujuk kepada kenaikan dan penurunan aras laut relatif dengan permukaan bumi. Ketidaktentuan paras pasang surut mempunyai kaitan dengan perubahan aras laut dan perubahan cuaca global (Tjia \& Sharifah Mastura 2013). Perubahan suhu permukaan laut mampu memberikan kesan dan perubahan kepada nilai bacaan pasang surut (Yuki et al. 2012).
Amnya, semua negara bersetuju bahawa datum carta adalah tikas air surut, di mana pada bila-bila masa kedalaman sebenar tidak akan berada lebih rendah daripada kedalaman yang tertera dalam carta nautika dan keadaan ini menyebabkan pelaut lebih berkeyakinan untuk belayar. Datum carta bersifat tempatan kerana ianya berbeza dari satu tempat ke satu tempat. Menurut Wright et al. (2007) dan Kavanagh (2009), datum carta diperlukan untuk membuat penyelarasan pengukuran di dalam kerja-kerja hidrografi.

Sehingga kini aras yang diguna pakai sebagai datum carta tidak seragam. Amerika Syarikat menggunakan aras Air Surut Paras Terendah manakala United Kingdom menggunakan Air Surut Falak Terendah dan Kanada pula mengguna pakai Air Surut Biasa Terendah walaupun IHO menyarankan penggunaan Pasang Surut Falak Terendah. Menurut IHO-S51(1993) perbezaan definisi aras datum 
carta secara global mendatangkan impak yang ketara bagi penentuan sempadan maritim kerana negara yang berjiran mungkin menggunakan aras datum yang berbeza dan tidak bersetuju dengan penggunaan datum negara jiran. Ia boleh menyebabkan pembahagian sempadan yang tidak sekata. Dalam kes ini, konsep garis sama jarak mungkin dipertikaikan. Amnya, perbezaan sifat pasang surut di seluruh dunia telah menyebabkan tatacara perolehan nilai datum, definisi tepat dan unggul bagi aras datum carta tidak dapat dipersetujui oleh masyarakat dunia sehingga kini. Ketidakseragaman dan kepastian berkenaan dengan Datum Carta akan mengakibatkan masalah di dalam penentuan sempadan negara Malaysia (Zaaim et al. 2008).

Menurut surat pekeliling IHO-CL80/2004 Aras Pasang Surut Falak Terendah (APSFT) merupakan aras paling sesuai bagi datum carta. Manakala IHO-S51 1993 pula menyatakan datum carta diperolehi melalui tempoh cerapan pasang surut sekurang-kurangnya sebulan. APSFT merupakan ketinggian terendah aras pasang surut dan ianya dihasilkan melalui ramalan pasang surut selama 19 tahun dengan mengunapakai pemalar harmonik yang di tentukan melalui tempoh cerapan. APSFT adalah nilai tersurut dalam ramalan pasang surut selama 19 tahun. Ia merupakan nilai rujukan kepada pengukuran hidrografi, penerbitan jadual pasang surut dan penerbitan carta nautika. Ketepatan ramalan pasang surut bergantung kepada nilai aras laut min dan siri amplitud dan fasa juzuk yang diguna pakai. Manakala kejituan aras laut min, siri amplitud dan fasa juzuk pula bergantung kepada tempoh cerapan data pasang surut yang diguna pakai. Algoritma bagi analisis harmonik dan ramalan menurut Luick (2004) adalah seperti berikut:

$$
H_{p}(t)=Z_{0}+\sum_{n=1}^{N}\left[f_{n} H_{n} \cos \left(\sigma_{n} t\right)-g_{n}+V_{n}\left(t_{0}\right)+U_{n}(t)\right],
$$

di mana,

$$
\begin{aligned}
N= & \text { jumlah harmonik atau juzuk pasang surut dalam } \\
& \text { model, } \\
Z_{0}= & \text { aras laut min, } \\
f_{n}= & \text { pembetulan faktor nod, } \\
H_{n}= & \text { amplitud bagi harmonik ke } n, \\
\sigma_{n}= & \text { kelajuan sudut (dalam darjah/ jam) bagi } \\
& \text { harmonik ke } n, \\
g_{n}= & \text { susulan fasa bagi harmonik ke } n \text { di belakang } \\
& V_{n}\left(t_{0}\right)+U_{n}\left(t_{0}\right), \text { diselaraskan untuk zon masa } \\
& \text { analisis. } \\
V_{n}\left(t_{0}\right)= & \text { fasa bagi juzuk pasang surut keseimbangan di } \\
& \text { Greenwich pada masa asalan, } \\
U_{n}= & \text { pembetulan bagi } V_{n}, \text { iaitu pembetulan fasa nod. }
\end{aligned}
$$

Kajian datum carta di pantai barat Taiwan oleh Chang dan Sun (2004) mendapati selisihan datum bulanan sebanyak $12.3 \mathrm{~cm}$ manakala kajian Swanson (NOAA 2003) mendapati bahawa anggaran ralat datum pasang surut pada 1 sigma $(\sigma)$ bagi cerapan satu bulan di pantai timur dan pantai barat Amerika Syarikat adalah sebanyak $0.08 \mathrm{~m}$ dan $0.11 \mathrm{~m}$. Objektif kajian adalah untuk memastikan datum carta yang digunapakai dapat disemak setelah berlakunya satu kitaran penuh nod bulan dan perubahan astronomikal yang berlaku. Justeru itu, ralat datum kawasan maritim negara harus dihuraikan kerana ia dapat memberi keyakinan dan ketepatan terhadap sesuatu pengukuran hidrografi.

\section{METODOLOGI}

Data cerapan pasang surut di stesen pasang surut Teluk Ewa selama 19 tahun diguna pakai bagi melaksanakan kajian ini. Julat data ini dicadangkan oleh Jabatan Ukur dan Pemetaan Malaysia (JUPEM) kerana nilainya yang konsisten. Data diproses dengan menggunakan perisian "RMN AseanAustralia Tidal Software" bagi memperoleh nilai datum carta bagi tempoh cerapan selama 19 tahun (Datum rujuk), tahunan, 6 bulan, 3 bulan dan 1 bulan. Analisis statistik dilakukan dengan menggunakan perisian SPSS bagi memperoleh perbezaan datum min, sisihan piawai dari datum rujuk dan datum min. Saiz ralat diukur pada tahap $2 \sigma$ sisihan piawai dan hasil analisis dihubungkaitkan dengan tahap piawai IHO. Lokasi kajian adalah seperti dalam Rajah 1.

Carta alir perlaksanaan kajian adalah seperti dalam Rajah 2. Nilai datum carta yang diperoleh merupakan ketinggian terendah dalam tempoh ramalan selama 19 tahun. Analisis harmonik menghasilkan siri amplitud dan susulan fasa juzukjuzuk pasang surut serta aras laut min. Juzuk-juzuk pasang surut digunakan untuk proses ramalan. Data-data di proses dengan menggunakan pelbagai set bacaan dan di lakukan analisis statistik dengan menggunakan perisian statistik. Hasil statistik dilakukan ujian piawaian berdasarkan kriteria IHO.

Secara teori, nilai datum yang paling sesuai diperoleh melalui cerapan 19 tahun kerana ia memenuhi kitaran penuh nod bulan dan mengambil kira semua perubahan astronomikal. Kitaran penuh nod bulan berlaku setiap 18.6 tahun (Baart et al. 2012 \& Tanaka et al. 2012). Oleh itu, penyelidik menggunakan datum carta bagi tempoh cerapan selama 19 tahun sebagai datum rujukan.

Model cerapan yang diguna pakai adalah seperti berikut:

1. 19 tahun (datum rujukan),

2. Tahunan (bagi tempoh selama 19 tahun),

3. 6 bulan (bagi tempoh selama 19 tahun),

4. 3 bulan (bagi tempoh selama 19 tahun), dan

5. 1 bulan (bagi tempoh selama 19 tahun).

Hasil yang diperolehi dianalisis secara statistik bagi ujian "normality" pada taburan datum dan taburan aras laut min, sisihan piawai dari min dan datum rujuk pada satu sigma $(1 \sigma)$ dan dua sigma $(2 \sigma)$. Kestabilan atau kebolehpercayaan juzuk tahunan dan bulanan diuji melalui nisbah ralat amplitud dan sisihan piawai amplitud dan susulan fasanya. Kajian statistik terhadap pemalar atau juzuk harmonik dilakukan bagi menentukan kestabilan dan keyakinan juzuk serta mengenalpasti juzuk yang sesuai digunakan bagi proses ramalan pasang surut. Sebanyak 112 juzuk dihasilkan melalui analisa harmonik bagi tempoh cerapan tahunan. Nilai amplitud dan fasa bagi juzuk tahunan (19 set), selama 19 


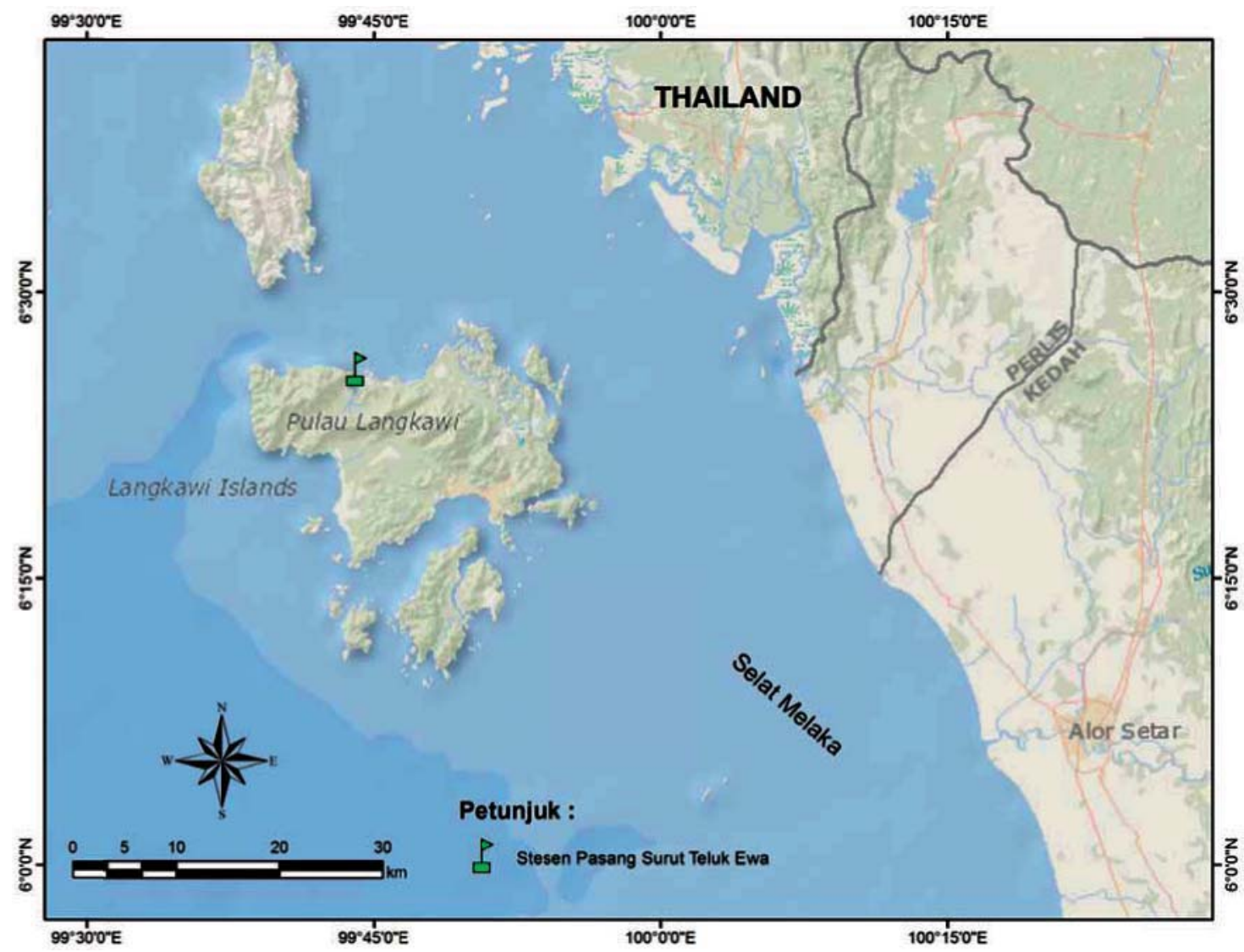

RAJAH 1. Lokasi Stesen pasang surut Teluk Ewa, Pulau Langkawi

tahun digunapakai untuk menghasilkan nisbah ralat amplitud dan sisihan piawai bagi amplitud dan susulan fasa tahunan.

Sebanyak 41 juzuk pasang surut dihasilkan melalui analisa harmonik bagi tempoh cerapan bulanan. Juzukjuzuk bulanan selama 35 bulan (35 set) digunakan untuk menghasilkan nisbah ralat amplitud dan sisihan piawai bagi amplitud dan susulan fasa bulanan. Kedua-dua parameter, nisbah ralat amplitud dan sisihan piawai susulan fasa dijadikan sebagai kriteria penerimaan/penolakan bagi juzuk yang digunakan untuk proses ramalan.

Tatacara berikut digunakan:

1. Memperolehi nilai purata amplitud, A dan fasa, $\theta$ serta selisihan piawai, $\sigma$ bagi juzuk .

2. Memperolehi nilai S (Min selisihan piawai bagi amplitud) dengan menggunakan persamaan $\mathrm{S}=$ $\sigma / \sqrt{ } \mathrm{n}$, dengan $\mathrm{n}$ sebagai jumlah cerapan.

3. Nisbah ralat amplitud adalah $r=\mathrm{S} / \mathrm{A}$.

4. Bagi ujian taburan T (two tailed student's t table) selama 19 tahun, kriteria penerimaan/penolakan adalah nisbah ralat amplitud kurang daripada $1 / 2.101$ (sekiranya degree of freedom $=18$ ) pada 95 peratus tahap keyakinan. Juzuk yang mempunyai nisbah ralat $>0.4759$ tidak diterima pakai bagi proses ramalan.

5. Kriteria penerimaan atau penolakan fasa adalah sisihan piawainya tidak melebihi $90^{\circ}$. Oleh itu, juzuk yang mempunyai sisihan piawai melebihi $90^{\circ}$ tidak diterima pakai untuk proses ramalan.

Perbandingan berikut dilaksanakan untuk menentukan kejituan juzuk pasang surut tempoh cerapan tahunan dan bulanan:

1. Sisihan piawai susulan fasa tahunan dan sisihan fasa bulanan.

2. Sisihan piawai amplitud tahunan dan bulanan.

3. Nisbah amplitud tahunan (amplitud tahunan/ amplitud 19 tahun) dan nisbah amplitud bulanan (amplitud bulanan/amplitud 19 tahun).

Hubung kait antara datum carta dan aras laut min juga diwujudkan melalui ujian korelasi dan regresi antara parameter tersebut. Sebanyak 60 sampel digunakan untuk menghasilkan pekali, $\mathrm{R}, \mathrm{R}^{2}$ dan fungsi garisan linear.

\section{KEPUTUSAN DAN PERBINCANGAN}

Hasil yang diperolehi menunjukkan kepada penemuan yang signifikan terhadap perubahan datum carta dan keperluan ketepatan pengukuran yang tinggi. Jadual 1 menunjukkan hasil ujian kenormalan Kolmogorov-Smirnov dengan nilai "sig" bagi semua tempoh cerapan adalah daripada 0.05. Ini bermakna taburan datum carta bagi semua tempoh cerapan 


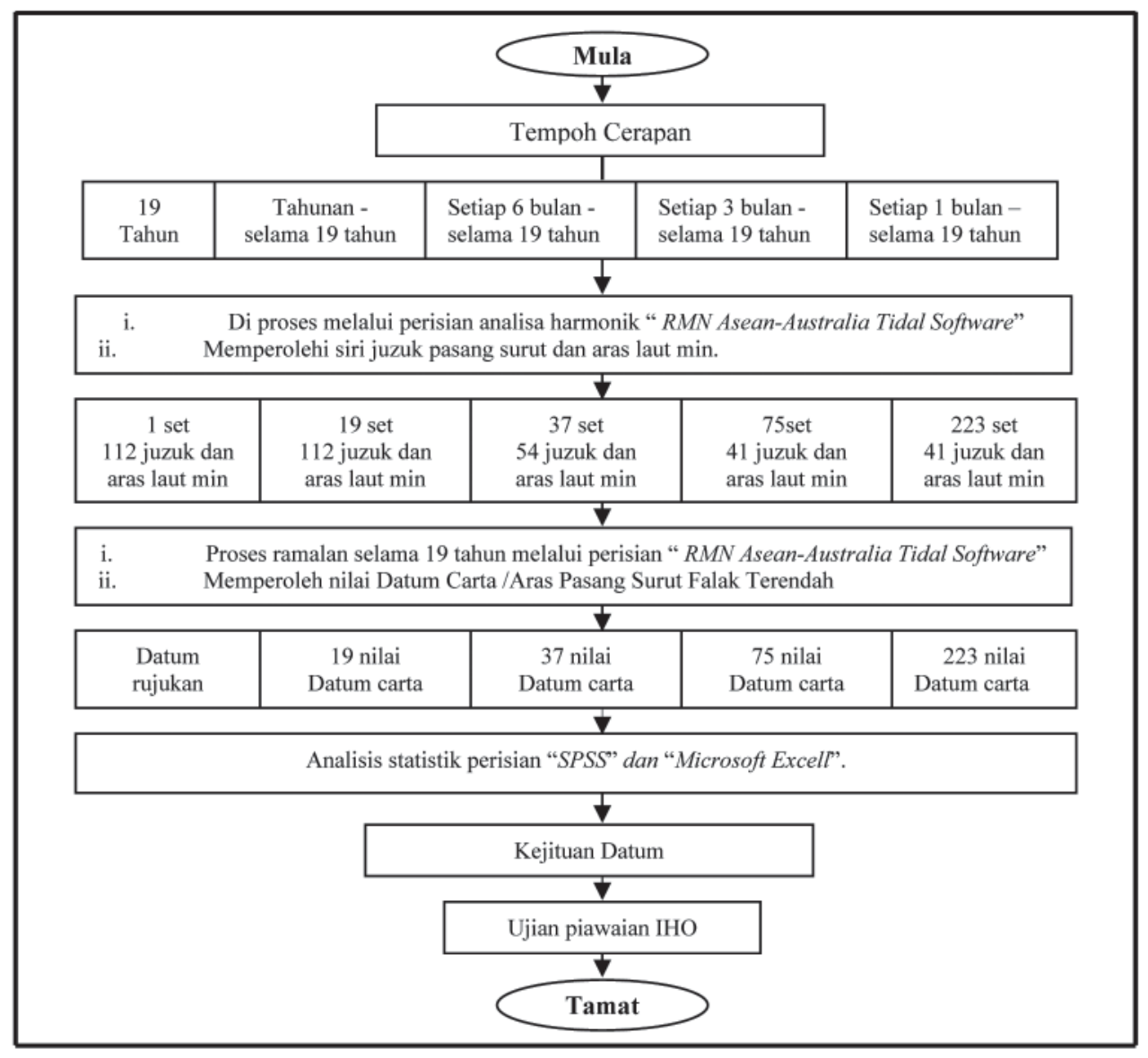

RAJAH 2. Carta alir analisis kejituan datum carta

adalah bersifat normal. Rajah 3 menggambarkan lengkungan yang berbentuk loceng menguatkan kesahihan ciri-ciri taburan normal.

JADUAL 1. Ujian kenormalan terhadap taburan datum carta

\begin{tabular}{cccc}
\hline & \multicolumn{3}{c}{ Kolmogorov-Smirnov(a) } \\
Datum Carta & Statistik & df & Sig. \\
\hline 1 Bulan & 0.041 & 223 & $0.200\left(^{*}\right)$ \\
3 Bulan & 0.072 & 75 & $0.200\left(^{*}\right)$ \\
6 Bulan & 0.102 & 37 & $0.200\left(^{*}\right)$ \\
1 Tahun & 0.093 & 19 & $0.200\left(^{*}\right)$ \\
\hline
\end{tabular}

* Nilai terendah yang signifikan

(a) Pembetulan "Lilliefors"

Jadual 2 menunjukkan datum carta min tahunan yang merekodkan sisihan paling hampir dengan datum rujukan. Bacaan bagi cerapan 3 bulan menunjukkan perbezaan yang besar dengan datum rujuk.

Jadual 3 menunjukkan datum carta bulanan merekodkan sisihan maksimum $(29 \mathrm{~cm})$ dan sisihan piawai yang paling tinggi jika dibandingkan dengan tempoh cerapan yang lain. Semakin panjang tempoh cerapan semakin baik sisihan piawainya manakala aliran sebaliknya berlaku apabila perbandingan perbezaan piawai min dianalisis. Perkara ini

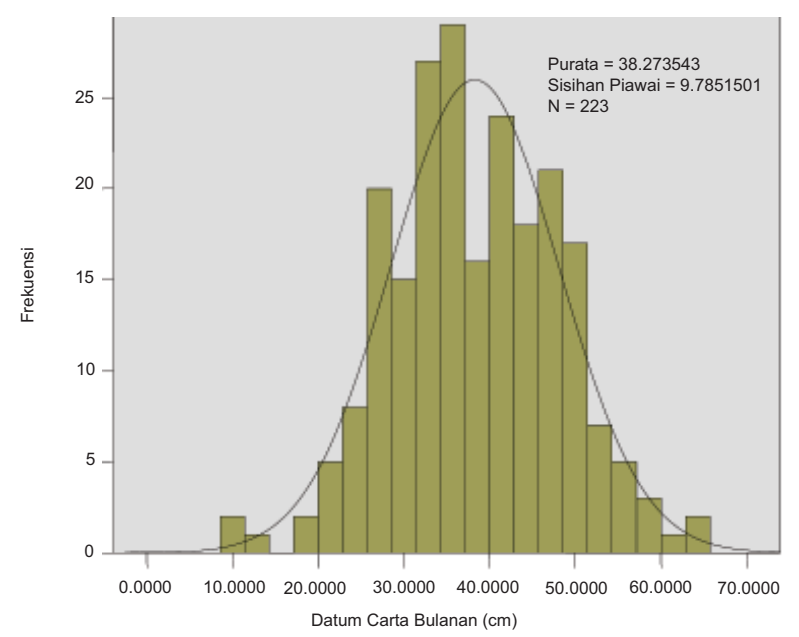

RAJAH 3. Taburan normal datum carta bulanan

JADUAL 2. Sisihan datum carta min dari datum rujukan

\begin{tabular}{ccc}
\hline $\begin{array}{c}\text { Tempoh Datum } \\
\text { Carta }\end{array}$ & $\begin{array}{c}\text { Datum Carta } \\
\text { Min }(\mathrm{cm})\end{array}$ & $\begin{array}{c}\text { Sisihan dari } \\
\text { Datum Rujuk } \\
38 \mathrm{~cm}(\mathrm{~cm})\end{array}$ \\
\hline Bulanan & 38.2735 & 0.2735 \\
3 bulan & 39.0133 & 1.0133 \\
6 bulan & 38.2432 & 0.2432 \\
Tahunan & 37.8947 & 0.1053 \\
\hline
\end{tabular}


timbul kerana jumlah data berbeza dan ianya bersesuaian dengan formula berikut:

Perbezaan piawai $\min =$ sisihan piawai $/ \sqrt{ }$ jumlah data

Oleh itu perbezaan datum dari min tidak digunakan sebagai pengukur saiz ralat dan sisihan piawai lebih sesuai diguna pakai bagi menjelaskan saiz ralat datum carta. Nilai julat Datum Carta yang tinggi pada tempoh cerapan bulanan $(55 \mathrm{~cm})$ menunjukkan terdapat beberapa data yang berada pada tahap terlampau atau unsur luaran pada tempoh tersebut.

JADUAL 3. Statistik deskriptif datum carta Teluk Ewa

\begin{tabular}{|c|c|c|c|c|c|c|c|}
\hline \multicolumn{8}{|c|}{ Analisis Statistik dalam $\mathrm{cm}$ (Datum Rujuk $=38 \mathrm{~cm}$ ) } \\
\hline Tempoh & Jumlah & Sisihan & Sisihan & Perbezaan & Sisihan & Julat & Sisihan \\
\hline Cerapan & Sampel & Piawai & $\begin{array}{c}\text { Piawai } \\
\text { dari Datum } \\
\text { Rujuk }\end{array}$ & Piawai & $\begin{array}{c}\text { Piawai } \\
2 \sigma \\
(1.9599 \sigma)\end{array}$ & $\begin{array}{c}\text { Datum } \\
\text { Carta }\end{array}$ & $\begin{array}{c}\text { Maksimum } \\
\text { dari Datum } \\
\text { Rujuk }\end{array}$ \\
\hline Tahunan & 19 & 5.724 & 5.725 & 1.313 & 11.220 & 21 & 11 \\
\hline 6 bulan & 37 & 5.997 & 6.002 & 0.986 & 11.763 & 27 & 16 \\
\hline 3 bulan & 75 & 7.082 & 7.154 & 0.818 & 14.021 & 43 & 26 \\
\hline 1 bulan & 223 & 9.785 & 9.791 & 0.655 & 19.189 & 55 & 29 \\
\hline
\end{tabular}

Rajah 4 menunjukkan Plot Batang - dan - Daun. Plot ini menunjukkan nilai datum bulanan yang dikategorikan sebagai terlampau atau menghampiri terlampau adalah nilai $=<10$ $\mathrm{cm}$ ( $2 \mathrm{kes})$ dan $62 \mathrm{~cm}=>$ ( $3 \mathrm{kes})$. Walaupun terdapat $2 \mathrm{kes}$ di mana nilainya dikategorikan sebagai terlampau/unsur luaran $(=<10 \mathrm{~cm})$ iaitu $9 \mathrm{~cm}$ dan $10 \mathrm{~cm}$ namun ia tidak menjejaskan taburan data yang normal. Nilai terlampau yang rendah telah menyebabkan pencong negatif kepada taburan data.

Berdasarkan kepada Rajah 5, rumusan datum carta pada kebarangkalian $2 \sigma(95.46 \%)$ mengikut tempoh cerapan adalah seperti berikut:

1. Tahunan: 95.46 peratus daripada nilai Datum Carta berada dalam lingkungan $38 \mathrm{~cm} \pm 11.22 \mathrm{~cm}$ (daripada $26.78 \mathrm{~cm}$ hingga $49.22 \mathrm{~cm}$ ). Kesemua data berada dalam lingkungan tersebut.

2. 6 bulan: 95.46 peratus daripada nilai datum carta berada dalam lingkungan $38 \mathrm{~cm} \pm 11.76 \mathrm{~cm}$ (daripada $26.24 \mathrm{~cm}$ hingga $49.76 \mathrm{~cm}$ ). 2.7 peratus data tidak berada dalam lingkungan tersebut.
3. 3 bulan: 95.46 peratus daripada nilai Datum Carta berada dalam lingkungan $38 \mathrm{~cm} \pm 14.02 \mathrm{~cm}$ (daripada $23.98 \mathrm{~cm}$ hingga $52.02 \mathrm{~cm}$ ). 4 peratus data tidak berada dalam lingkungan tersebut.

4. 1 bulan: 95.46 peratus daripada nilai Datum Carta berada dalam lingkungan $38 \mathrm{~cm} \pm 19.19 \mathrm{~cm}$ (daripada $18.81 \mathrm{~cm}$ hingga $57.19 \mathrm{~cm}$ ). 3.6 peratus data tidak berada dalam lingkungan tersebut.

Manakala pada kebarangkalian $1 \sigma(68.27 \%)$ rumusan datum carta mengikut tempoh cerapan adalah seperti berikut:

1. Tahunan: dianggarkan $68.27 \%$ daripada nilai Datum Carta berada dalam lingkungan $38 \mathrm{~cm} \pm 5.73 \mathrm{~cm}$ (daripada $32.27 \mathrm{~cm}$ hingga $43.73 \mathrm{~cm}$ ) $21.1 \%$ data tidak berada dalam lingkungan tersebut.

2. 6 bulan: dianggarkan $68.27 \%$ daripada nilai Datum Carta berada dalam lingkungan $38 \mathrm{~cm} \pm 6.00 \mathrm{~cm}$ (daripada $32 \mathrm{~cm}$ hingga $44 \mathrm{~cm}$ ) $27 \%$ data tidak berada dalam lingkungan tersebut.

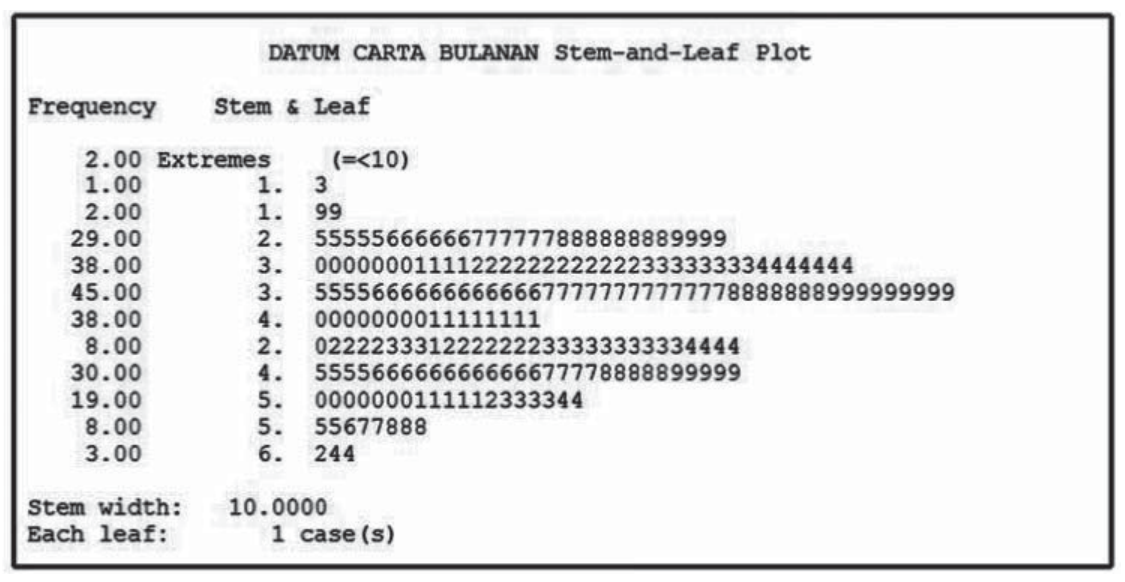

RAJAH 4. Plot Batang-dan Daun bagi nilai datum carta bulanan 
3. 3 bulan: dianggarkan $68.27 \%$ daripada nilai Datum Carta berada dalam lingkungan $38 \mathrm{~cm} \pm 7.15 \mathrm{~cm}$ (daripada $30.85 \mathrm{~cm}$ hingga $45.15 \mathrm{~cm}$ ). $25.3 \%$ data tidak berada dalam lingkungan tersebut.

4. 1 bulan: dianggarkan $68.27 \%$ daripada nilai Datum Carta berada dalam lingkungan $38 \mathrm{~cm} \pm 9.79 \mathrm{~cm}$ (daripada $28.21 \mathrm{~cm}$ hingga $47.79 \mathrm{~cm}$ ). $36.3 \%$ data tidak berada dalam lingkungan tersebut.

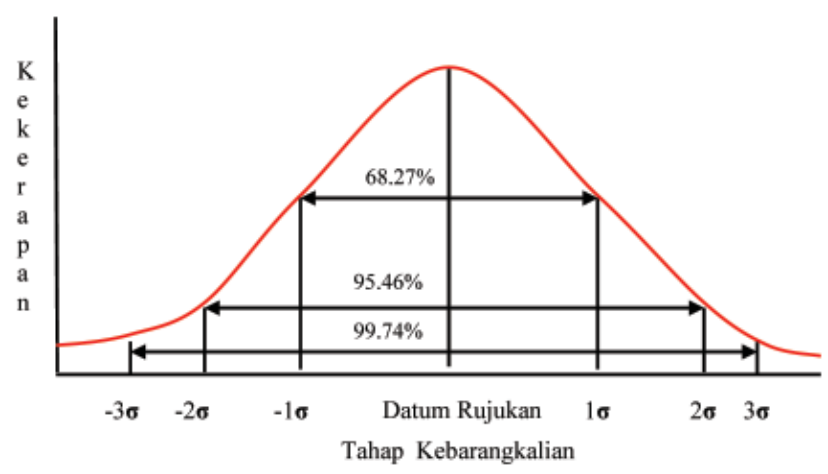

RAJAH 5. Lengkung kebarangkalian dan saiz ralat $1 \sigma, 2 \sigma$ dan $3 \sigma$

Hasil kajian menunjukkan datum carta bagi tempoh cerapan tahunan mempunyai peratusan taburan data paling jitu kerana 78.9 peratus daripada nilai datumnya berada dalam lingkungan $1 \sigma$ dan 100 peratus daripada nilai datumnya dalam lingkungan $2 \sigma$. IHO-S44 (1998) menetapkan bahawa ralat pada datum carta tidak melebihi $5 \mathrm{~cm}$ bagi pengukuran kelas khas dan $10 \mathrm{~cm}$ bagi pengukuran kelas 1dan ke bawah dan nilai ralat pada datum carta ini tidak dipinda dalam piawaian kerja hidrografi edisi 2008 (IHO-S44,2008). Hasil analisis pada Rajah 6 jelas menunjukkan bahawa sisihan pada $1 \sigma$ berada di bawah $10 \mathrm{~cm}$ bagi semua tempoh cerapan. Manakala pada sisihan $2 \sigma$ semua tempoh cerapan yang diuji tidak menepati kedua-dua kelas pengukuran yang dinyatakan. Walaupun demikian sisihan bagi tempoh cerapan 1 tahun tidak pernah melewati $10 \mathrm{~cm}$ sepanjang 19 tahun. Tambahan pula, pada anggaran kebarangkalian 95.4 peratus $(2 \sigma)$ mendapati kesemua datum tahunan berada dalam lingkungan $38 \mathrm{~cm} \pm$
$11.22 \mathrm{~cm}$ dan penghampiran dengan nilai ralat pada datum ini menunjukkan kestabilan data tahunan baik walaupun ia tidak mencapai tahap IHO pada tahap $2 \sigma$. Nilai datum carta bagi tempoh 5 tahun juga telah diproses, sisihan piawainya dari datum rujuk adalah $3.69 \mathrm{~cm}$ pada $1 \sigma$.

\section{KESIMPULAN DAN CADANGAN}

Kajian datum carta di stesen pasang surut Teluk Ewa, Langkawi jelas menunjukkan bahawa tempoh cerapan kurang daripada 1 tahun tidak dapat memenuhi kehendak IHO pada tahap 2 sigma. Penggunaan datum carta yang jitu amat penting bagi tugas hidrografi yang memerlukan ketepatan yang tinggi seperti penentuan titik pangkal negara. Natijahnya, penggunaan datum carta yang dihasilkan daripada cerapan kurang 1 tahun boleh menyebabkan negara kerugian zon maritim terutama sekali di kawasan pengukuran yang mempunyai kecerunan pesisir depan yang landai. Kejadian pasang surut adalah berbeza dari lokasi ke lokasi atau bersifat "site specific". Kajian ini juga dapat meningkatkan lagi kejituan ramalan pasang surut sedia ada dengan penggunaan juzuk-juzuk yang dihasilkan melalui tempoh 19 tahun.

\section{PENGHARGAAN}

Penulis menyampaikan rasa terima kasih kepada Tentera Laut Diraja Malaysia dan Jabatan Ukur dan Pemetaan Malaysia, di atas data-data dan kerjasama yang dihulurkan. Penulis juga ingin merakamkan penghargaan kepada Universiti Kebangsaan Malaysia di atas tajaan penyelidikan melalui Geran Galakan Penyelidik Muda GGPM-2014-021 dan Geran Universiti Penyelidikan - GUP-2014-038.

$$
\text { RUJUKAN }
$$

Baart, F., van Gelder, P. H. A. J. M., de Ronde, J., van Koningsveld, M. \& Wouters, B. 2012. The Effect of the 18.6-year lunar nodal cycle on regional sea-level rise estimates. Journal of Coastal Research 28(2): 511-516

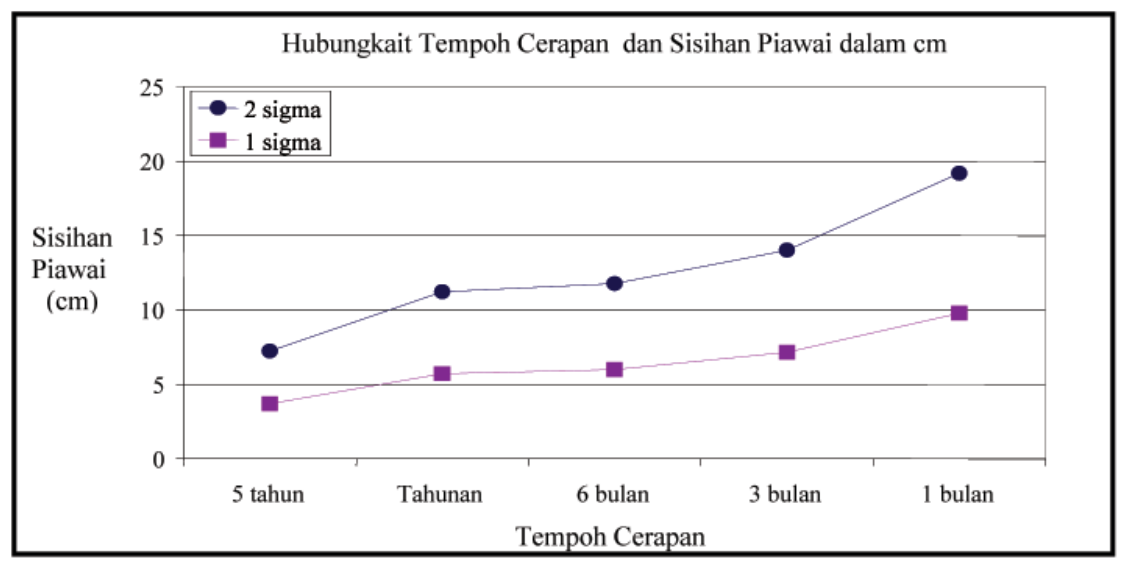

RAJAH 6. Sisihan pada $1 \sigma$ dan $2 \sigma$ 
Chang, C. C. \& Sun, Y. D. 2004. Application of a GPSbased method to tidal datum transfer. The Hydrographic Journal 112: 15-20.

Charlier, R. H. \& Finkl, C. W. 2009. Ocean Energy: Tide and Tidal Power. Berlin: Springer.

Estopinal, S. V. 2009. A Guide to Understanding Land Surveys. United States of America: John Wiley \& Sons.

IHO-CL 80/2004. 2004. Datums and Bench Marks. International Hydrographic Bureau, Monaco, 1 Disember.

IHO-S44. 1998. Standard For Hydrographic Surveys. Special Publication No. 44. $4^{\text {th }}$ Edition. Monaco: International Hydographic Bureau.

IHO-S44. 2008. Standard For Hydrographic Surveys. Special Publication No. 44. $5^{\text {th }}$ Edition. Monaco: International Hydographic Bureau.

IHO-S51. 1993. A Manual on Technical Aspects of the United Nations Convention on The Law of the Sea-1982. Special Publication No. 51. $3^{\text {rd }}$ Edition. Monaco: International Hydographic Bureau.

Jabatan Ukur dan Pemetaan Malaysia. 2006. Salinan data digital cerapan pasang surut setiap jam bagi stesen tetap tolok pasang surut Teluk Ewa, Pulau Langkawi dari tempoh 1986 hingga 2014 dalam format DNM. Kuala Lumpur: Jabatan Ukur dan Pemetaan, Malaysia.
Kavanagh, B. F. 2009. Surveying: Principles and Applications. $8^{\text {th }}$ Edition. New Jersey: Prentice Hall.

Luick, J. L. 2004. Australian Tidal Handbook. Adelaide: Australian Government, Bureau of Meteorology.

Mills, J. \& Dodd, D. 2014. Ellipsoidally Referenced Surveying for Hydrography. Helsinki: International Federation of Surveyors (FIG).

NOAA. 2003. Computational Techniques for Tidal Datum Handbook. Maryland: US Department of Commerce.

Tanaka, Y., Yasuda, I., Hasumi, H., Tatebe, H. \& Osafune, S. 2012. Effects of the 18.6-yr modulation of tidal mixing on the north pacific bidecadal climate variability in a coupled climate model. Journal of Climate 25: 7625 7642.

Tjia, H. D. \& Sharifah Mastura, S. A, 2013, Sea Level Changes in Peninsular Malaysia. Bangi: Penerbit UKM.

Wright, D. J., Blongewicz, M. J., Halpin, P. N. \& Breman, J. 2007. Arc Marine: GIS for a Blue Planet. United Stated of America: ESRI Press.

Zaaim Hasan, Othman A. Karim \& Khairul Nizam Abdul Maulud, 2008, Impak perubahan datum carta dan kecerunan pesisir depan terhadap ketidakpastian kedudukan titik pangkal Malaysia. Sains Malaysiana 37(2): 123-130.

Othman A. Karim

Jabatan Kejuruteraan Awam dan Struktur,

Fakulti Kejuruteraan dan Alam Bina,

Universiti Kebangsaan Malaysia,

43600 UKM, Bangi,

Selangor Darul Ehsan, Malaysia

*Penulis koresponden; emel: knam@ukm.edu.my

Tarikh serahan: 30 Mac 2015

Tarikh terima: 8 Jun 2015

43600 UKM, Bangi

Selangor Darul Ehsan, Malaysia

Zaaim bin Hasan

Pusat Hidrografi Nasional,

Bandar Armada Putra,

Pulau Indah, 42009 Pelabuhan Klang,

Selangor Darul Ehsan, Malaysia 